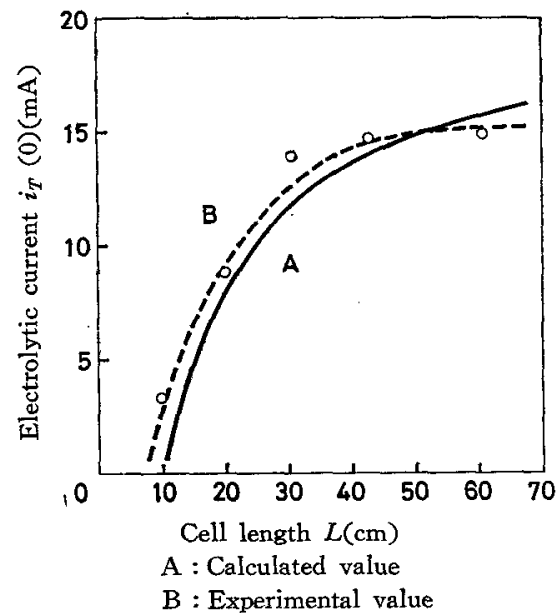

Fig. 10 Electrolytic current vs. cell length ている.

\section{5 総 括 (Summary)}

著者らは金属の線条材の電解処理方式としていわゆる 対極を使用しない電解方式を開発したが，この方式の特 徵を明らかにするために，比較的簡単な等価回路を想定 乙, 電極反応の電流電位曲線を電流密度の 1 次関数で近 似することによって，全電解電流，電流分布などについ ての理論式を誘導した.さらにこれらを実証するため に, 径 $10 \mu$ のタングステン線执よび1規定カセイソー ダ水溶液を用いて，実験を扔こなった，その結果，この 電流電位曲線は, 低電流密度領域以外では, 1 次関数で 近似できた．また，全電流と全電解電流，全電流とソウ 電圧, ソウ長と全電解電流の各相関関係について, 理論
值と実験值は比較的よい一致を示した。したがって，以 上の結果から，この種の電解方式の巨視的な考察に対し てここで誘導した理論式が，十分適用できることがかか った.

(Received April 6 1968)

記 号

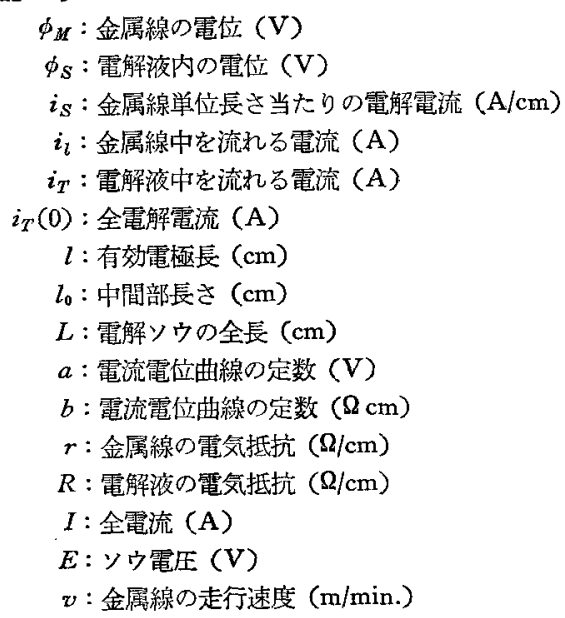

なお，陽極部，陰極部で異なる量については添字 $a, c$ ，をつは て区别する。

\section{文献}

1)たとえば A.K. Graham, "Electroplating Engineering Handbook" 2 nd Edition p. 605, p. 616 (1962), Reinhold Publishing Co.

2) B.E. Conway, E. Gileadi, H.G. Oswin, Can. J. Chem. 41, 2447 (1963).

S.K. Rangarajan, M.J. Dignam, B.E. Conway, ibid. 45. 422 (1967).

J. Wojtowicz, L. Laliberté, B.E. Conway, Electrochimica: Acta 13, 361 (1968).

3) W.W. Harvey, J. Electrochem. Soc. 109, 638 (1962).

4) 中路幸謙, “電気化学用電気技衍” p. 52 (1961), 才一ム社.

\title{
定電位法によるクロム酸溶液の電解還 元*
}

\author{
木 村 肇**，林 忠 夫**

\section{Potentiostatic Study on the Electrolytic Reduction of Chromic Acid Solutions} \\ Hajime KimUra and Tadao HAYASHI \\ (Department of Applied Chemistry, Univ. of Osaka Prefecture,
Mozu-Umemachi, Sakai, Osaka
}

Study was carried out on the electrolytic reduction of chromic acid solutions in the presence of anions such as $\mathrm{SO}_{4}{ }^{2-}, \mathrm{Cl}^{-}, \mathrm{NO}_{3}{ }^{-}$and $\mathrm{SiF}_{6}{ }^{2-}$ on $\mathrm{Pt}, \mathrm{Au}$ and $\mathrm{Ni}$ electrodes.

Cathode potential-current density curves were measured by the potentiostatic (potential sweep) method. 
The reduction of chromic acid was found to take place in several steps and the potentiostatic polarization curves showed some sudden transients caused by the formation of resistive layers on the electrodes.

Anions such as $\mathrm{SO}_{4}{ }^{2-}, \mathrm{Cl}^{-}, \mathrm{NO}_{3}{ }^{-}$and $\mathrm{SiF}_{6}{ }^{2-}$ are shown to have the specific influence on the reduction of chromic acid, that is, a partial reduction current corresponding to the reaction of $\mathrm{Cr}^{6+}$ $\rightarrow \mathrm{Cr}^{3+}$, appeared before hydrogen evolution and chromium deposition.

In the potential regions more negative than $-1.0 \mathrm{~V}$ (vs. S.C.E.), chromium begins to deposit at the electrodes accompanying with hydrogen evolution and the process is found to be affected by the cathodic passivation of the electrodes.

With an increase in the sweep rate of the potential, the polarization curves are shifted to the more negative potentials and it is difficult to distinguish each reaction step in the electrolytic reduction of chromic acid solution.

\section{1 緒 言 (Introduction)}

一般にクロムメッキ浴として用いられているクロム 酸一硫酸溶液を電解還元する場合のクロム電着反応機構 については, Liebreich ${ }^{1)} の \mathrm{Cr}^{6+} \rightarrow \mathrm{Cr}^{3+} \rightarrow \mathrm{Cr}^{2+} \rightarrow \mathrm{Cr}^{0}$ のような段階的還元説, $\mathrm{Mülller}^{2)}, \mathrm{Kasper}^{3)}$ の $\mathrm{Cr}^{6+} \rightarrow$ $\mathrm{Cr}^{0}$ 直接還元説, Snavely ${ }^{4)}$ の原子状水素による還元説 などがある。

これらの説については Brenner ら"のトレーサー法 による実験によって一応の解決が得られているがな抢不 明な点当多い。

このようなクロム電着機構についての問題は 1954 年 頃より再び活発になり，ドイツにおいて Knorr 学派 ${ }^{6)}$ による定電流法执よび定電位法による分極曲線の詳細な 検討が行なわれ，Müller の説を裹づける実験結果が得 られた．Weiner”るクロム電着について長年にわたり 庆沉な研究を行ない電着機構について新しい考え方を述 ベている.

Gerischer $5^{8)}$ は定電位法による分極曲線の解析を行 ならとともにクロム電着反応の中間過程に生成する陸 極皮膜の構造について半導体説加ら説明を試みた。一 方，岡田ら は はnorr らとほとんど同じ時期に，黒色 クロムメッキの電着機構の解明にその端緒をおき，電着 物の構造の変化, 各種方法による分極曲楾について詳し い検討を行ない，ク口ム酸溶液の電解還元反応について 新しい知見を得た。

ソ連においてもクロム電着についての研究は非常に盛 んで多くの成果 ${ }^{(0)}$ が発表されているが，その概要につい ては Ryan ${ }^{11)}$ の総説がある。

このよらなクロム電着機構についてのいるいらな説が 提案される要因としては，電極反応にともなら陰極分極 曲線の複雑さ，陰極上に拄けるクロメ一ト皮膜の生成反 応に対する各種電気化学的測定法の取り扱い方, および 測定值の再現性の問題などが考えられるが，ク口ム電着 機構の解明にはクロメート皮膜生成反応に伴う陰極不働 態化現象の解析が重要なテーマと考えられる.

本実験に扔いては白金，金ニッケル電極を用い，各
種濃度のクロム酸溶液に硫酸, 塩酸, 硝酸あるいはケイ フッ化ナトリウムを添加した浴について定電位法による 電流一電位曲線を測定し，クロム電着の中間過程として 重要な役割をなすクロメート皮膜の生成機構について検 討した。

\section{2 実験方法 (Experimental)}

\section{1 電 解 液}

クロム酸溶液はクロム酸に適量のアニオンを添加して 調製した。クムム酸に不純物として含まれる硫酸イオン はク口ム酸バリウムを加え硫酸バリウムとして沈んで除 去した。

アニオンとして用いた硫酸，塩酸，硝酸俚市販特級試 薬を，またケイフッ化ナトリウムは森田化学製の化学試 薬をそのまま用いた。

\section{2 電解ソウ}

電解ソウは二重のガラス製ソウで陽極室に陰極室をグ ラスフィルターで仕切ったH型セルで恒温水をセルの外 側に通すことによって測定温度を調節した．測定温度は すがて $30^{\circ} \mathrm{C}\left( \pm 0.5^{\circ} \mathrm{C}\right)$ とした。

\section{3 電 極}

陰極は白金，金およびニッケル電極（ $(0.5 \mathrm{~mm}$, 面積 $0.1 \mathrm{~cm}^{2}$ ）学用い，陽極には白金板它使用した。

ニッケル電極は白金線上へワット浴 $\left(\mathrm{NiSO}_{4} \cdot 7 \mathrm{H}_{2} \mathrm{O}\right.$ $\left.240 \mathrm{~g} / l, \mathrm{NiCl}_{2} \cdot 6 \mathrm{H}_{2} \mathrm{O} 45 \mathrm{~g} / l, \mathrm{H}_{3} \mathrm{BO}_{3} 30 \mathrm{~g} / l\right)$ を用いて $45^{\circ} \mathrm{C}$, 電流密度 $4 \mathrm{~A} / \mathrm{dm}^{2}$ で $20 \mu$ のニッケルメッキを 行なったものである。

電極電位の測定に照合電極として飽和かんこう電極 (S.C.E.) を用いた。

\section{4 電極の前処理}

試料陰極注測定に使用する前に, 白金電極注 Kolthoff, Tanaka ${ }^{123}$ の方法に基うき， $10 \mathrm{~N} \mathrm{HNO}_{3}$ に浸せきした のち, 水洗し, $1 \mathrm{~N} \mathrm{H}_{2} \mathrm{SO}_{4}$ 溶液中で飽和かんこう電極 と数分間短絡処理を行なった。金電極は $80 \% \mathrm{H}_{2} \mathrm{SO}_{4}$ 中 で電流密度 $10 \sim 20 \mathrm{~A} / \mathrm{dm}^{2}$ で僢間的に陰極還元処理を 行ない表面酸化物を除去した。ニッケル電極は白金電極 上にワット浴を用いニックルメッキを行ない，水洗して 


\section{ただちに使用した.}

また白金，金電極では陰極にクロメート皮膜あるいは 金属クロム分析出した場合は $4 N \mathrm{NaOH}$ 中で陽極処理 を行ない，溶解除去した。ニッケル電極の場合は新しく メッキしたものを用いた。

\section{5 測 定}

電流-電位曲線はいわゆるポテンシャルスイープ法に より測定した. ポテンシォスタット (日业計器製 HP$1 \mathrm{~A}$ 型) に外部加電位自動加減装置 (日亜計器製) あ るいは低周波発振器 (日西計器製特殊波形発生器) を用 いて三角波電位を加え, 試料電極を自然電極電位加ら 分極させ，X-Y レコーダー（松下通信機製 MD-511 S 型ににより電流一電位曲線を記録した。

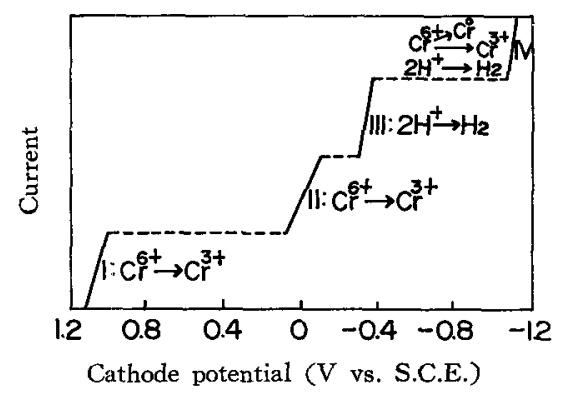

Fig. 1 The schematic representation of the cathodic polarization curve in chromium plating solution by galvanostatic method

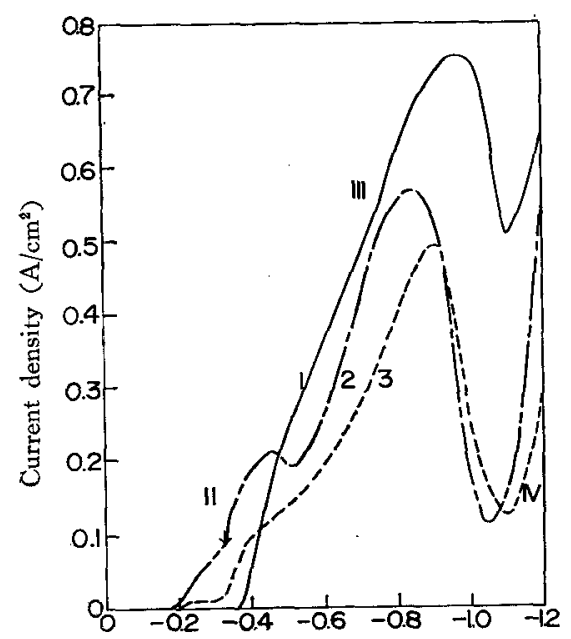

Cathode potential (V vs. S.C.E.)

$1: 2.5 M \mathrm{CrO}_{8}$

$2: 2.5 M \mathrm{CrO}_{3}, 0.025 M \mathrm{H}_{2} \mathrm{SO}_{4}$

$3: 0.4 M \mathrm{CrO}_{9}, 0.004 \mathrm{M} \mathrm{H}_{2} \mathrm{SO}_{4}$

Potential sweep rate: $20 \mathrm{mV} / \mathrm{min}$

Fig. 2 Cathodic polarization curves for Pt electrode

\section{3 実験結果と考察 (Results and Discussion)}

通常のクロムメッキ浴を定電流法によって定常分極曲 線を厳密に測定すると Fig. 1 に示すように 4 つの不連 続な枝に分かれ，それぞれの分極電位において図中に示 したような電極反応が起こるものと考えられている6 寸なわち，第I枝においては陰極表面の酸化物の還元と 同時に $\mathrm{Cr}^{6+} \rightarrow \mathrm{Cr}^{3+}$ の反応が, 第正枝では $\mathrm{Cr}^{6+} \rightarrow \mathrm{Cr}^{3+}$

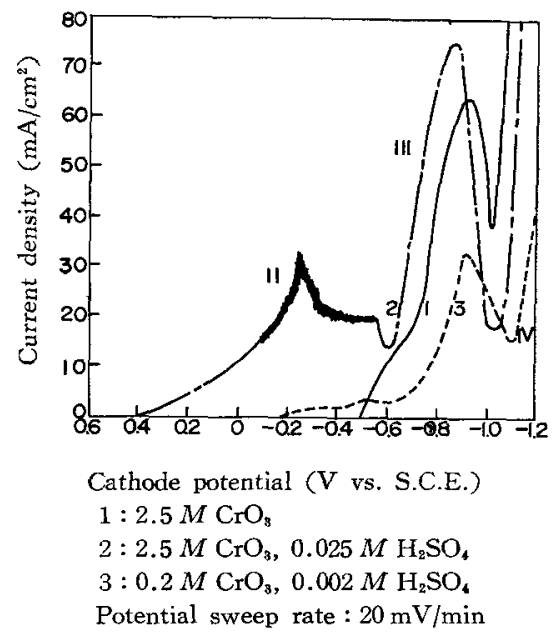

Fig. 3 Cathodic polarization curves for Au electrode

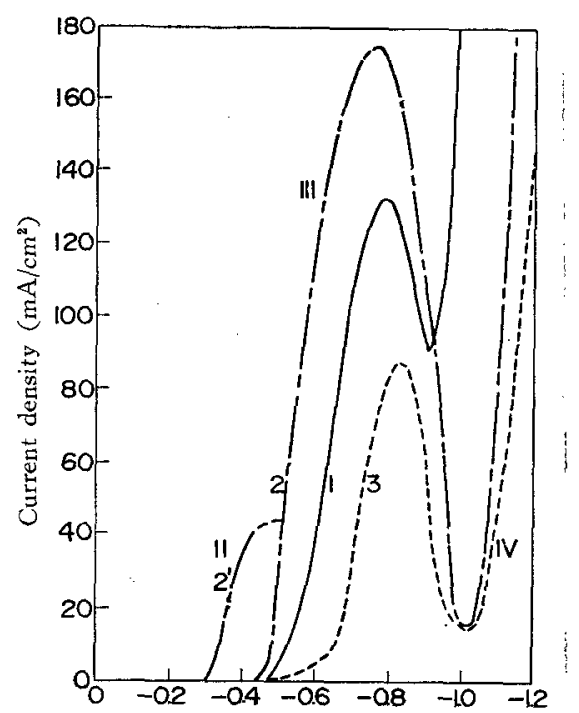

Cathode potential (V vs. S.C.E.) $1: 2.5 \mathrm{M} \mathrm{CrO}_{8}$ $2: 2.5 M \mathrm{CrO}_{3}, 0.025 M \mathrm{H}_{2} \mathrm{SO}_{4}$ $3: 0.4 M \mathrm{CrO}_{3}, 0.004 M \mathrm{H}_{2} \mathrm{SO}_{4}$ Potential sweep rate $: 20 \mathrm{mV} / \mathrm{min}$

Fig. 4 Cathodic polarization curves for $\mathrm{Ni}$ electrode 
の反応, 第 $\mathrm{III}$ 枝では $2 \mathrm{H}^{+} \rightarrow \mathrm{H}_{2}$ の反応, 第 IV 枝では $\mathrm{Cr}^{6+} \rightarrow \mathrm{Cr}^{3+}, 2 \mathrm{H}^{+} \rightarrow \mathrm{H}_{2}, \mathrm{Cr}^{8+} \rightarrow \mathrm{Cr}^{0}$ の反忘㖣同時に 起こる.

したがって本実娩においても分極曲線に認められるそ れぞれの反応段階に相当する電位領域から電極反忘を考 察することにした。

\section{1 定電位法に上る電流-電位曲線}

3.1.1 純粋なクロム酸溶液 一般に純粋なクロム 酸溶液の電解還元においては, 金属クロムは析出せず, 少量のアニオンを添加することによってはじめてクロム メッキが可能になることはよく知られている.

Fig. 2〜4の曲線 1 に純粋なクロム酸溶液について定 電位法*による電流一電位曲線の測定結果を示した。

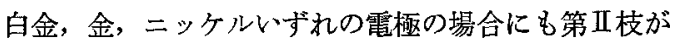
認められなく，第亚枝に相当する電位範围（約 $-0.4 \mathrm{~V}$ vs. S.C.E.) に達したのちはじめて雪流が流れ, クロム 酸の還元が水素発生と同時に起こるものと考えられる。

3.1.2 硫酸を添加した浴 一方, Fig. 2〜4の曲 線 2 およ゙ 3 に示したように，クロ公酸溶液に硫酸を添 加した場合の電流一電位曲線には白金, 金, ニッケル電 極いずれの場合む水素発生電位より貫な電位において， $\mathrm{Cr}^{6+} \rightarrow \mathrm{Cr}^{3+}$ の還元反忘による電流が認められる.

Fig. 2 の白金電極の場合は約 $-0.2 \mathrm{~V}$ 加ら電流が認 められ，曲線2 のいわゆるサージェント浴の場合，電位 が卑になるにしたがって電流が大きくなっているが，第 II枝の途中約 $-0.3 \mathrm{~V}$ のころで 分極曲線に屈曲点が 認められ，第枝加第 III 枝へ移行する $-0.4 \sim-0.5$ $\mathrm{V}$ の電位範囲江括いて電流の下降現象, 、わゆる陰極 不働態化現象が現われている。また，第吕枝から第IV枝 への移行過程である約 $-0.8 \sim-1.0 \mathrm{~V}$ の電位範囲で著 しい電流の下降を経て第 $N$ 枝にいたり，金属クロムの析 出が起こるむのと考えられる.

クロム酸および硫酸の淟度がともに低い場合 $(0.4 M$ $\mathrm{CrO}_{3}, 0.004 M \mathrm{H}_{2} \mathrm{SO}_{4}$ ) (曲線 3 ) はサージェント浴の よらなクロム酸濃度の高、浴に比べて全電位範囲にわた り電流値はかなり減少しているが，第亚枝から第 $\mathrm{N}$ 枝へ 移行する過程において分極曲線に極大および極小が認め られ，第IV枝の電位において金属クロムが析出すること を確認した.このことは, 非常に希薄なク口ム酸溶液に おいても,クロム酸と硫酸の濃度の割合が適当な場合は 通常のクロムメッキ浴加らクロム電着とほぼ同し過程 を経て，クロム析出が起こることを示すものである.

Fig. 3 の金電極にお打る電流-電位曲線も白金電極の 場合と同じ傾向を示している.サージェント浴（曲線 2) においては第岓に相当する $-0.1 \sim-0.6 \mathrm{~V}$ の電

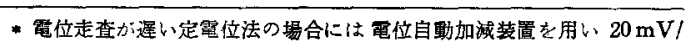

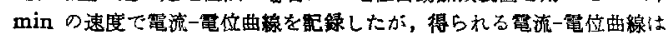
定常法による测定とほ仿一教することがわかった。
位範囲で電流の振動現象が認められたが，これ法金電極 上に生成したクロメート皮膜が硫酸によって溶解，生成 を繰り返すためと考えられる。このことは，純粋なク口 ム酸（曲線 1) あるい注電解液濃度とくに硫酸濃度が低 、浴（曲線 3）に注認められないことから理解できる。

一方，第而枝に拉けるクロメート皮膜の変化が完了す ると, 第 III 枝以後の電位に招ける電流-電位曲線はいず れの浴についても白金電極の場合とよく類似している. しかし，曲線 2 のサージェント浴に見られるよらに，金 電極に挨いては, 第 II 枝の $\mathrm{Cr}^{6+} \rightarrow \mathrm{Cr}^{3+}$ によるクロム 酸の還元電流が認められるのは約 $+0.4 \mathrm{~V}$ であり，白 金の場合（約 $-0.2 \mathrm{~V}$ ) に比べて非常に貴な電位になっ ている.この現象電極金属のちがいによることは明ら かであり, Müller ${ }^{13)}$ はこの点について，金は水素を吸 蔵する性質がないのに対し，白金は水素を吸蔵する性質 をもつといら観点から説明している。

この上うに, クロム酸溶液の電解還元に打ける電流電位曲線は電極金属の性質によってかなり変化すること がわかる.さらに, ニッケル電極の場合には電極の表面 状態 (酸化状態)によっても電流-電位曲線に著しい変 化が認められた.

すなわち，Fig. 4 は白金および金電極の場合と同様 に, ニッケル電極を用いて自然電極電位（サージェント 浴の場合, 約 $+0.7 \mathrm{~V})$ から杽な方向電位を掃引した 場合であるが，いずれの浴においても曲線 1 の純粋なク 口ム酸溶液の場合と同じ電位から電流が流れており, 分

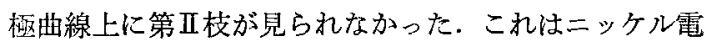
極をク口ム酸溶液に浸せきしたときニックルがクロム 酸の酸化作用によって, その表面にニッケル酸化物皮膜 を生じ，電極表面が不働態化した結果と考えられる。そ こで，クロム酸溶液にニックル電極を浸せきする場合, ポテンシォスタットにより陰極電位を自然電極電位より かなり早な電位 $(+0.1 \mathrm{~V})$ 亿設定し, その電位から力 ソード方向に電位を掃引し, 電流一電位曲線を測定した ところ,サージェント浴の場合注約 $-0.3 \mathrm{~V}$ から第I 枝に相当する $\mathrm{Cr}^{6+} \rightarrow \mathrm{Cr}^{3+}$ の還元反応にもとづく電流 が認められた (曲線 $2^{\prime}$ ).

また，Fig. 2 4 から明らかなよらに，同一組成の浴 の場合，白金電極に比べて金括よびニッケル電極におけ る還元電流はいずれの電位においても著しく小さい.こ れは各金属の水素過電圧のちがいによるものと考えられ

Table 1 Minimum hydrogen overpotential at various electrodes

\begin{tabular}{c|c|c}
\hline Cathode material & Electrolyte & Overpotential (mV) \\
\hline Platinum & $2 \mathrm{~N} \mathrm{H}_{2} \mathrm{SO}$ & 0.002 \\
Gold & $"$ & 16.5 \\
Nickel & $"$ & 137.5 \\
\hline
\end{tabular}


る. Table $1^{14)}$ に示したように，白金は金およびニッケ ルに比べて水素過電圧が著しく小さいことがわかる.

3.1.3 硫酸以外のアニオンを添加した浴 Fig. 5 に $2.5 \mathrm{M} \mathrm{CrO}_{3}$ に $\mathrm{Na}_{2} \mathrm{SiF}_{6}, \mathrm{HCl}, \mathrm{HNO}_{3}$ をそれぞれ $0.025 M$ 添加した浴の白金電極に扔ける電流-電位曲線 を示した. クロム酸溶液に硫酸を添加した浴と同様に， 式れの浴についても水素発生電位に達寸る前に, $\mathrm{Cr}^{6+}$ $\rightarrow \mathrm{Cr}^{3+}$ の還元電流が認为られ，分極曲線に法いわゆる 第I枝がはっきり現われている。

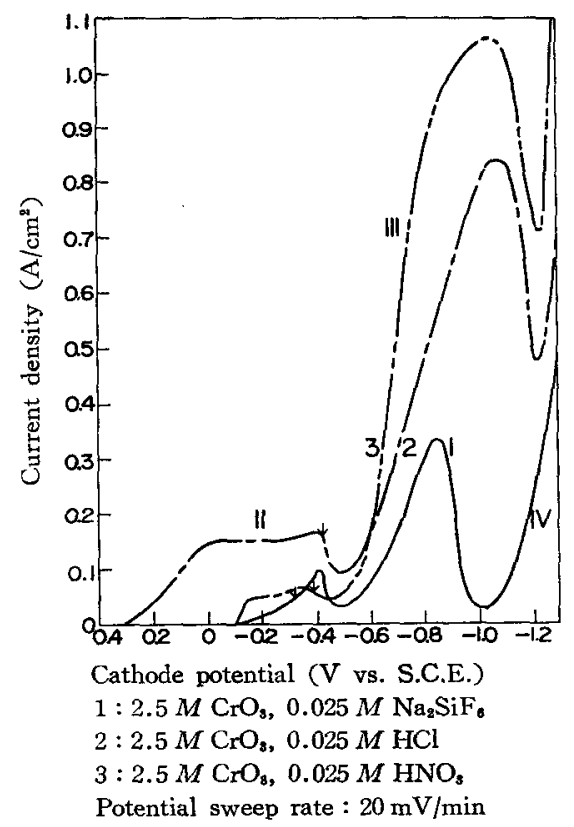

Fig. 5 Cathodic polarization curves on Pt electrode

塩酸掞よび硝酸を添加した浴の第枝において，ある 電位範囲で限界電流が認められ，さらに杽な電位になっ て，皮膜の変化に対応寸る電流ピークを越えたところか ら水素の発生が見られた（図中の矢印は肉眼で水素の発 生が観測された電位を示す)。

一方，ケイフッ化ナトリウムを添加した浴（曲線 1） では，硫酸の場合 (Fig. 2 の曲線 2 ) と同様に水素の 発生が起こってから電流のピークが現われている.

また，塩酸および硝酸を添加した浴の場合には，硫酸 扔よびケイフッ化ナトリウムの場合に比べて非常に大き な還元電流が認められ，これらのアニオンのクロメート 皮膜の溶解作用が著しいことを示している．しかし，第 林枝加第IV枝への移行過程にある電流の下降は小さ く，とくに硝酸の場合に桜純粋なク口ム酸溶液と同じ く，第枝において金属クロムの析出が認められず，陰 極に黒色の皮膜が見られた.

このようにアニオンの種類によっても電流一電位曲線 に著しい影響が認妨ら，とくに第亚枝から第IV枝への
電流の下降現象，すなわち陰極上に生ずるクロメート皮 膜の変化がクロム析出反応に重要な役割を果しているこ とがわかった。

\section{2 電位走查法による電流-電位曲線}

Fig. 6 のサージェント浴における白金電極の自然電 極電位は約 $+1.0 \mathrm{~V}$ (vs. S.C.E.) であり,この電位か ら電位走查速度 $60 \mathrm{mV} / \mathrm{sec}$ でカソード方向纪 電位を印 加した場合，約 $-0.2 \mathrm{~V}$ までは電流が非常に小さく， 電極表面が不活性になっていることがわかる。

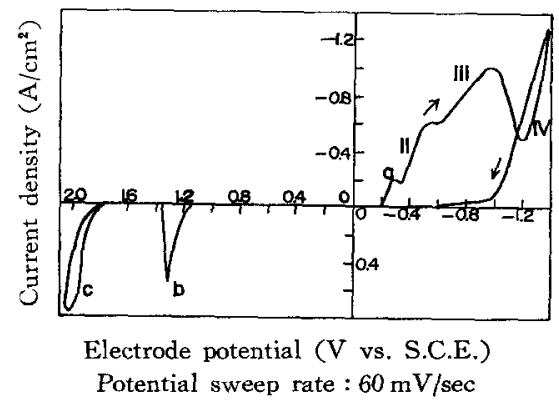

Fig. 6 Polarization curve for Pt electrode in $2.5 \mathrm{M} \mathrm{CrO}_{3}+0.025 \mathrm{M} \mathrm{H}_{2} \mathrm{SO}_{4}$

Fig. 6 の結果を Fig. 2 の電位走查が遅い場 合 $(20$ $\mathrm{mV} / \mathrm{min}$ ) と比較するとわかるように，第I枝の途中に 電流ピーク（Fig. 6 のa）が現われている. 第 II 枝で 起こる反応は一般に $\mathrm{Cr}^{6+} \rightarrow \mathrm{Cr}^{3+}$ であると考えられて いるが，第II枝の電位籍围でも比較的早な電位に招いて は $\mathrm{Cr}^{6+} \rightarrow \mathrm{Cr}^{3+}$ と同時に, 一部分 $2 \mathrm{H}^{+} \rightarrow \mathrm{H}_{2}$ による反 応電流が流れているものと考元られる。したがって，こ のようなかなり速い電位走查による急激な電位変化は大 きな還元電流を与え，そのた陰極近傍で硫酸イオンが 欠乏し，皮膜の状態が変化するものと考元られる．この 皮膜の変化は Fig. 2 の曲線 2 における約 $-0.3 \mathrm{~V}$ の ところにある䜿曲点に相当するものと思われ，事実，そ の電位に拉いて水素ガスの発生が誌められた。

第W枝に達したのち，電位を再びアノード方向へもぼ して行くと, 約 $-0.6 \mathrm{~V}$ 加電流は著しく減少し, 約 $+1.2 \mathrm{~V}$ に達して析出したクロムの溶解 $\left(\mathrm{Cr}^{\circ} \rightarrow \mathrm{Cr}^{6+}\right)$ による電流ピーク (Fig. 6 のb) が認められる.さらに 貴な電位 (約 $+1.8 \mathrm{~V}$ ) には酸素の発生による電流ピ一 ク (Fig. 6 のc) が認められた。

Fig. 7 は雪位走査速度 $30 \sim 180 \mathrm{mV} / \mathrm{sec}$ で測定した 電流一電位曲線 を示したが，電位走查が速くなるにした がって，次第に電流值が增大し，曲線の形状もそれにと もなって変化している。すなわち電流一電位曲線が全体 に曳な方向に移行し，第I枝加第而枝への移行過程に 見られる電流の下降現象ははっきり認められず，この段 階に招けるクロメート皮膜の変化は電位の変化に十分追 随できない性質のものであることが推定される.また， 


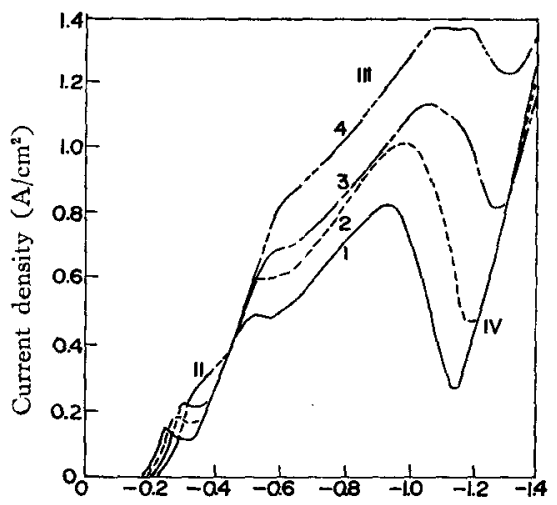

Cathode potential (V vs. S.C.E.) Potential sweep rate $1: 30 \mathrm{mV} / \mathrm{sec}, 2: 60 \mathrm{mV} / \mathrm{sec}$ $3: 90 \mathrm{mV} / \mathrm{sec}, 4: 180 \mathrm{mV} / \mathrm{sec}$

Fig. 7 Effect of sweep rate of the potential on the polarization curves for $\mathrm{Pt}$ electrode in $2.5 \mathrm{M} \mathrm{\textrm {CrO } _ { 3 } +}$ $0.025 \mathrm{M} \mathrm{H}_{2} \mathrm{SO}_{4}$

第而枝加ら第IV枝への移行過程は曲線 4 に扔いて顕著に 見られるように，あまり電位走查が速いとクロメート皮 膜が完全に変化しないまま, 第而枝加ら第IV枝の底応段 階に移行するものと考えられる。

\section{4 総 括 (Summary)}

定電位電解法によるクロム酸溶液の電解䢬元を行ない 電流一電位曲線を測定した結果，次のことがわかった。

（1）分極曲線に電流の極大および極小丸゙現われ，い わゆる陰極不働態化現象が認められ，クロメート皮膜が 電位によって変化することがわかった．また，クロム酸 溶液の濃度が希薄な場合にもこの現象が認められた。

（2）純粋なクロム酸溶液の場合注陰極分極曲線にい わゆる第III枝が認められなかった.アニオンを添加した 浴に执いては $\mathrm{Cr}^{6+} \rightarrow \mathrm{Cr}^{3+}$ の還元反応による第吕枝が 認められ，この第I枝の電流が現われる電位はアニオン の種類によって異なり，クロメート皮膜に対するアニオ
ンの溶解作用の差異を示すものであり，关た，陰極金属 およびその表面状態の影響をうけることがわかった。

(3) 第吕枝に㧍ける 電流一電位曲線は純粋なクロム 酸溶液のそれとよく類似しており，電極で起こっている 反忘汏部分水素発生反心であると考えられる.

第 IV 枝におけるクロム析Hは第枝から第 IV枝への移 行過程汇見られる陰極不衝態化現象によって影響を5 け，陰極不働態化電流が大きい場合には金属クロムの析 佶が起こりにくいことがわかった。

(4) 電位走查が速くなるにしたがって電流-電位曲 線汢全体に早なう向に移行し, 各枝八の移行過程に認め られる電流の下降現象は任っきりせず，クロメート皮膜 の変化が完全に行なわれず，反店は次の段階に進むもの 上考えられる.

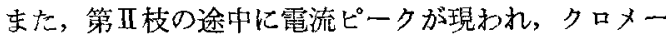
卜皮膜の変化に対虑して電極反応も変化し，この電位よ り一部分水素発生反忘が起こるものと考えられる。

(Received Oct. 15 1968)

\section{文}

\section{献}

1) E. Liebreich, Z. Elektrochem. 27, 94 (1921).

2) E. Müller, ibid. 32, 399 (1926), ibid. 50, 172 (1944).

3) C. Kasper, J. Research Natl. Bur. Standards 9, 353 (1932).

4) C.A. Snavely, J. Electrochem. Soc. 92, 537 (1947).

5) F. Ogburn, A. Brenner, ibid. 96, 347 (1949).

6) D. Reinkowski, C.A. Knorr, Z. Elektrochem. 58, 709 (1954).

7) R. Weiner, Metal Finishing 64, 46 (1966).

8) H.Gerischer, M. Kappel, Z. Elektrochem. 61, 463 (1957).

9）阔田秀弥，石田武男，金属表面技術 11，623(1960).

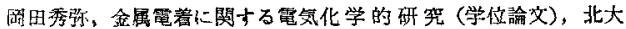
(1962).

10) Contributions to the Theory of Chromium Plating (Academy of Sciences of U.S.S.R.) (1965).

Theory and Practice of Chromium Electroplating (ibid.) (1965).

11) N.E. Ryan, Metal Finishing 63, 46 (1965), ibid. 63, 73 (1965).

12) J.M. Kolthoff, N. Tanaka, Anal. Chem. 26, 632 (1954).

13) E. Muller, Z. Elektrochem. 49, 16 (1943).

14）外島忍，基礎電気化学 p. 333 朝倉夆店. 